\title{
sciendo
}

\section{RELATIONSHIP BETWEEN POLYMORPHISM WITHIN PEPTIDOGLYCAN RECOGNITION PROTEIN 1 GENE (PGLYRPI) AND SOMATIC CELL COUNTS IN MILK OF HOLSTEIN COWS*}

\author{
Tadeusz Zabolewicz, Paulina Puckowska, Paweł Brym, Kamil Oleński, Stanisław Kamiński* \\ Department of Animal Genetics, University of Warmia and Mazury in Olsztyn, Oczapowskiego 5, 10-719 Olsztyn, Poland \\ •Corresponding author: stanislaw.kaminski@uwm.edu.pl
}

\begin{abstract}
Bovine peptidoglycan recognition protein 1 (PGLYRP1) is an important receptor that binds to murein peptidoglycans (PGN) of Grampositive and Gram-negative bacteria and is, therefore, involved in innate immunity. The SNP T $>$ C rs68268284 located in the 1 st exon of the PGLYRP1 gene was identified by the PCR-RFLP method in a population of 319 Holstein cows. Somatic cell count (SCC) was measured 7-10 times in each of three completed lactations to investigate whether the PGLYRP1 polymorphism is associated with SCC. Using the GLM model, it was found that cows with the TT genotype showed significantly lower somatic cell counts than those with the CC genotype during the first lactation ( $\mathrm{P}=\mathbf{0 . 0 2 3}$ ). Moreover, during lactations $1-2$ and $1-3$, cows with the TT genotype reveal significantly lower SCC than CT heterozygotes, at $\mathbf{P}=\mathbf{0 . 0 2 5}$ and $\mathbf{P}=\mathbf{0 . 0 0 6}$, respectively. Computer-aided analysis showed that rs68268284 polymorphism could modify the PGLYRP1 functions because the mutated residue is located in a domain that is important for the binding of other molecules.
\end{abstract}

Key words: PGLYRP1 gene, polymorphism, mastitis, Holstein cattle

Among all dairy cattle diseases, mastitis is the most serious problem in the dairy industry worldwide since it causes high economic losses and public health concerns (Kossaibati and Esslemont, 1997; Seegers et al., 2003). This disease also results in physical and chemical changes in the milk and negatively influences its quality (Detilleux et al., 2015). Moreover, subclinical forms of mastitis disturb the fertility of high-yielding cows (Siatka et al., 2018). Mastitis is preceded by a subclinical udder condition, which is manifested by an increase in somatic cell count (SCC).

Genetic markers are assumed to be linked with the gene for the trait of interest and therefore are helping in quantitative trait loci (QTL) detection and in marker assisted selection (MAS). MAS is best applied for traits that have low heritability and are sex-limited (Raina et al., 2020). The results of many studies conducted in various populations of Holstein-Friesian cattle have shown a presence of quantitative trait loci for udder health located in chromosome 18 (Kühn et al., 2003; Baes et al., 2009; Brand et al., 2009; Ibeagha-Awemu et al., 2016; Marete et al., 2018). QTLs cover relatively large chromosome fragments containing many functional genes potentially involved in the trait of interest. Therefore, a functional approach focusing on genes that are biologically related to the trait contributes to a better understanding of the genetic architecture of the trait.

Studying the genes shaping the defense mechanisms of the cow udder (Walawski et al., 1999; Wellnitz and Bruckmaier, 2012; Litwińczuk et al., 2015) and taking into account their optimal variants in genetic selection seemed to be a way of breaking the impasse in the battle against mastitis in high production herds (Sender et al., 2013).

Cole et al. (2011) identified an SNP marker (rs 108993234) as a QTL peak for somatic cell score (SCS), located at a distance of $409 \mathrm{bp}$ from the PGLYRP1 gene.

Bovine peptidoglycan recognition protein 1 (PGLYRP1) is an important pattern receptor that binds to murein peptidoglycans (PGN) of Gram-positive bacteria. PGLYRPs have been found in many species of organisms (Dziarski, 2004; Dziarski and Gupta, 2006). They display bactericidal activity towards Gram-positive bacteria and may kill Gram-positive bacteria by interfering with peptidoglycan biosynthesis. PGLYRP1 also binds to Gramnegative bacteria and is involved in innate immunity and exerts microbicidal activity towards Gram-positive and Gram-negative bacteria and yeast (Tydell et al., 2006). PGLYRP1 is also highly expressed in bone marrow. The mRNA of PGLYRP in human peripheral leukocyte was

*The work was supported by University of Warmia and Mazury, grant no 01050804. 
detected by Kang et al. (1998), and its primary expression in mammalian neutrophils was confirmed by Liu et al. (2000). The mature protein is stored in the cytoplasmic granules of eosinophils and neutrophils but is absent in monocytes, lymphocytes and platelets (Tydell et al., 2002). McConnel et al. (2020) identified PGLYRP1 gene expression in peripheral bovine leukocytes that was upregulated during the early stages of mastitis regardless of differences in breeds, parities, days in milk, production levels or pregnancy status.

The direct proximity of the PGLYRPI gene to an SNP marker (rs 108993234) was indicated by Cole et al. (2011) as a highly relevant marker for SCC, which encouraged the authors to undertake research on the search for functional polymorphism in the coding sequence of the PGLYRPl gene. The Ensembl database (ENSBTAT00000003414.3) contains 66 records of missense SNPs of PGLYRP1 gene but only T $>$ C rs68268284 was confirmed by a previous study as encountered in an HF population and is likely to affect protein function based on sequence homology and the physical and chemical similarity between the alternate amino acids (SHIFT http://sift.bii.astar.edu.sg/). Seabury and Womack (2008) first detected 11 SNPs in the PGLYRP1 gene by a comparative sequence analysis of ten domestic cattle breeds. Moreover, Seabury et al. (2010), using PolyPhen and SHIFT software, found that nonsynonymous SNP rs68268284 encoding amino acid substitution was expected to potentially impact protein function. Pant et al. (2011) identified three single nucleotide polymorphisms (SNPs) in the gene encoding bovine peptidoglycan recognition protein 1: two synonymous located at position $+102 \mathrm{C} / \mathrm{G},+480 \mathrm{G} / \mathrm{A}$, and one $+2001 \mathrm{~A} / \mathrm{C}(+$ means start translation) in the 3' untranslated region (UTR). Wang et al. (2013) found 10 SNPs: $-35 \mathrm{~A} / \mathrm{T},-28 \mathrm{~A}>\mathrm{C},-27 \mathrm{~A}>\mathrm{G}$, $-12 \mathrm{G}>\mathrm{T}$ located in promotor of the gene, $+102 \mathrm{C}>\mathrm{G}$ and $+226 \mathrm{~A}>\mathrm{G}$ in the first exon, $+312 \mathrm{~A}>\mathrm{G},+649 \mathrm{C}>\mathrm{G}$, $+1658 \mathrm{C}>\mathrm{T}$ in introns and $+2001 \mathrm{~A}>\mathrm{C}$ located in $3^{\prime}$ ' UTR.

The SNP $\mathrm{T}>\mathrm{C}$ rs68268284 located in the first exon of the PGLYRP1 gene was selected in this study because of its missense effect: the substitution of amino acid Tyrosine by Histidine $(\mathrm{Y} 76 \mathrm{H})$, which can modify the PGLYRP1 protein function.

The present study was designed to estimate the allele and genotype frequencies of PGLYRP1 rs68268284 and the association of its variants with somatic cell counts and production traits in Holstein cattle.

\section{Material and methods}

\section{Experimental animals}

A total of 319 cows of the Holstein breed held in two herds (all having three completed lactations standardized for 305 milking days) were included in the study. Their SCC was measured 7-10 times during lactation and scored in an official milk recording system (SYMLEK). Because of the inhomogeneous frequency distri- butions, the SCC mean values of each analyzed period were transformed into a logarithmic form with a base of ten. The cows were held in free-stall barns under similar conditions. The feeding system (established over both the winter and summer seasons) was based on TMR (Total Mixed Ration). Samples of ear tissue (collected routinely for animal identification system) were used for genomic DNA extraction and were taken according to ethical guidelines (Local Ethical Commission approval No. 50/2015/N).

\section{PCR-RFLP}

The pair of primers (forward: 5'GGAGAAACAGACGTTGCAGG3' and reverse: 5'TCCCCGTAGATAAAGGCCCA3') was used to amplify a 452 bp fragment of $P G L Y R P 1$ gene. Primers were designed based on a genome sequence (NCBI Reference Sequence: NC_037345.1 REGION: 53513719...53515780), using Primer3 software (Koressaar et al., 2018).

The PCR thermal profile was as follows: pre-denaturation $-3 \mathrm{~min}$ at $94^{\circ} \mathrm{C}, 35$ cycles of $94^{\circ} \mathrm{C}$ for $30 \mathrm{~s}, 59^{\circ} \mathrm{C}$ for $30 \mathrm{~s}$ and $72^{\circ} \mathrm{C}$ for $30 \mathrm{~s}$, and a final extension at $72^{\circ} \mathrm{C}$ for $5 \mathrm{~min}$. PCR was performed in a $25-\mu \mathrm{L}$ reaction mix, containing 20-40 ng of genomic DNA, $0.5 \mu \mathrm{L}(50 \mu \mathrm{M})$ of each primer, $2.5 \mu \mathrm{L}$ KAPA Taq Buffer A (10x) (KAPA Biosystems, USA), $2 \mu \mathrm{L}$ dNTPs mix (2.5 mM each), 2.5 units of KAPA Taq DNA Polymerase and deionized water added to reach a volume of $25 \mu \mathrm{L}$. The PCR products were digested with Fast Digest Rsa I (Thermo Scientific, USA) following the producer's protocol. The Sanger sequencing method was used to confirm genotypes.

\section{Statistical analysis}

A Chi-square test was performed to confirm the hypothesis that the population under study is at the HardyWeinberg equilibrium for PGLYRP1 T>C rs68268284 polymorphism.

The obtained results were analyzed by the GLM (General Linear Model) procedure in Statistica software ver. 13.3 (StatSoft, Inc. 2018). The distribution of SCC mean values (log transformed) of a cow's first lactation, first with second lactation and combined 1st, 2nd and 3rd lactations were tested by chi-square test for goodness of fit. The homogeneities of variance were estimated by Levene's test.

The following linear model was used to analyze the association of SNP T $>$ C rs68268284 genotype with SCC during three lactations:

$$
\text { Yijklmn }=\mu+G i+S j+A k+P l+H m+F n \text { eijklmn }
$$

where: Yijklmn - ijklmn-th observation, $\mu$ - overall mean, $G i$ - fixed effect of ith genotype $(i=1-3), S j-$ random effects of j-th sire $(j=1-67), A k$ - fixed effect of k-th age of calving $(k=1-21, k=1-25, k=1-34), P l-$ fixed effect of 1 -th calving season $(l=1,2), H m$ - fixed effect of $m$-th herd $(m=1,2), F n$ - fixed effect of n-th 
milk yield class $(n=1(<6000 \mathrm{~kg}), 2(6001-9000 \mathrm{~kg})$, $3(>9001 \mathrm{~kg})$ and eijklmn - the random error.

The Tukey adjustment was used.

\section{In silico analysis of the PGLYRP1 T $>C$ rs68268284} mutation effect

The relevant mutation UniProt Q8SPP7, ENSBTAP00000003414.3:p.Tyr76His was analyzed using HOPE software (http://www3.cmbi.ru.nl/hope/) (Venselaar et al., 2010).

\section{Linkage disequilibrium}

Two hundred and sixty-four Holstein cows and bulls genotyped by the Illumina Bov54kSNP chip were used to estimate linkage disequilibrium among SNP rs 108993234 (ARS-BFGL-NGS-117985; Cole et al., 2011) located 406 bp outside the PGLYRP1 gene and six
SNPs flanking this region. The analysis was conducted using SNP \& Variation Suite v8.8.3 (Golden Helix, Inc., Bozeman, MT).

\section{Results}

SNP detection and gene phenotype analysis

Identification of the polymorphism within the $P G$ $L Y R P 1$ exon 1 was confirmed in ten randomly selected cows (Figure 1).

Amplicons of good quality were digested by the RsaI restriction enzyme to reveal a genotype for PGLYRPexon 1. Three patterns of amplicon fragments were observed: TT $-294 \mathrm{bp}$ and $158 \mathrm{bp} ; \mathrm{CC}-452 \mathrm{bp} ; \mathrm{CT}-452$ bp, 294 bp and 158 bp (Figure 2).

Table 1. Characterization of the main milk production traits recorded during three complete lactations

\begin{tabular}{|c|c|c|c|c|c|c|c|c|c|c|c|c|c|c|c|}
\hline \multirow{2}{*}{ Herd } & \multirow{2}{*}{$\mathrm{N}$} & \multicolumn{2}{|c|}{ MY (kg) } & \multicolumn{2}{|c|}{ FY (kg) } & \multicolumn{2}{|c|}{ FP $(\%)$} & \multicolumn{2}{|c|}{ PY (kg) } & \multicolumn{2}{|c|}{ PP (\%) } & \multicolumn{2}{|c|}{$\mathrm{S}(\mathrm{kg})$} & \multicolumn{2}{|c|}{ SP (\%) } \\
\hline & & $\bar{x}$ & SE & $\bar{x}$ & SE & $\overline{\mathrm{x}}$ & SE & $\overline{\mathrm{x}}$ & SE & $\overline{\mathrm{x}}$ & $\mathrm{SE}$ & $\overline{\mathrm{x}}$ & SE & $\overline{\mathrm{x}}$ & SE \\
\hline A & 124 & 6844 & 115 & 277 & 4 & 4.09 & 0.04 & 227 & 4 & 3.39 & 0.04 & 882 & 14 & 13.30 & 0.24 \\
\hline B & 195 & 8918 & 92 & 392 & 5 & 4.40 & 0.03 & 303 & 3 & 3.50 & 0.03 & 1188 & 12 & 13.65 & 0.12 \\
\hline Total & 319 & 8112 & 91 & 347 & 4 & 4.28 & 0.03 & 274 & 3 & 3.46 & 0.03 & 1069 & 12 & 13.52 & 0.12 \\
\hline
\end{tabular}

MY - Milk Yield, FY - Fat Yield, FP - Fat Percentage, PY - Protein Yield, PP - Protein Percentage, S - Solids, SP - Solids Percentage.

250

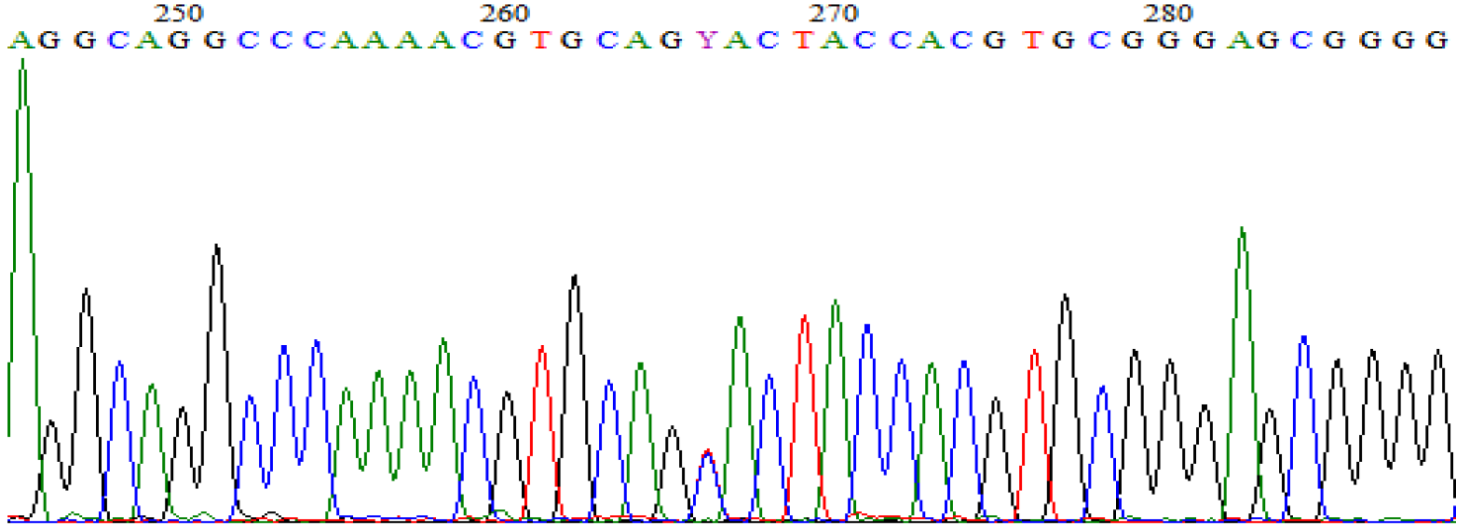

Figure 1. Detection of T > C polymorphism within PGLYRP1 exon 1 by sequencing. A: allele T coding Tyrosine (Y). B: allele C coding Histidine $(\mathrm{H})$. C: heterozygote TC. A sequence of a 452 bp amplicon was compared with the NCBI Reference Sequence: NC_037345.1

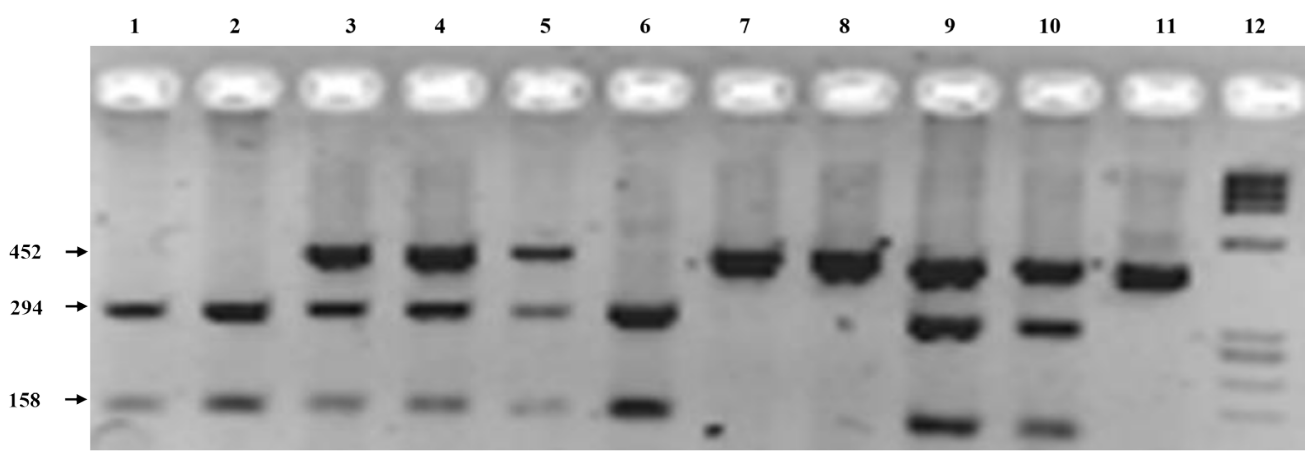

Figure 2. Examples of genotyping of PGLYRP1 SNP T $>$ C rs68268284). A 452 bp amplicon was digested with restriction enzyme RsaI. Lines 1 , 2 and 6 genotype TT; lines 3, 4, 5, 9 and 10 genotype TC; lines 7, 8 and 11 genotype CC; line 12 molecular DNA size marker PhiX 174 Hae III 
Table 2 . Frequency of genotypes and alleles for PGLYRP1 SNP T $>$ C rs68268284 in the studied population of 319 Holstein cows

\begin{tabular}{ccc|cccccc}
\hline & \multicolumn{2}{c}{ Genotype } & \multicolumn{2}{c}{ Allele } \\
\hline & number & & & frequency & & \\
\hline CC & CT & TT & CC & CT & TT & C \\
30 & 176 & 113 & 0.10 & 0.55 & 0.35 & 0.37 \\
\hline
\end{tabular}

Table 3. Association between PGLYRP1 gene polymorphism and milk production traits and SCC (log10) during three lactations

\begin{tabular}{|c|c|c|c|c|c|c|c|c|}
\hline \multirow{4}{*}{ Lactation } & \multirow{4}{*}{ Traits } & \multicolumn{6}{|c|}{ PGLYRP1 } & \multirow{4}{*}{ P-value } \\
\hline & & \multirow{2}{*}{\multicolumn{2}{|c|}{$\begin{array}{c}\mathrm{TT} \\
\mathrm{N}=113\end{array}$}} & \multirow{2}{*}{\multicolumn{2}{|c|}{$\begin{array}{c}\mathrm{CT} \\
\mathrm{N}=176\end{array}$}} & \multirow{2}{*}{\multicolumn{2}{|c|}{$\begin{array}{c}\mathrm{CC} \\
\mathrm{N}=30\end{array}$}} & \\
\hline & & & & & & & & \\
\hline & & $\overline{\mathrm{x}}$ & SE & $\overline{\mathrm{x}}$ & SE & $\overline{\mathrm{x}}$ & $\mathrm{SE}$ & \\
\hline \multirow{8}{*}{1} & MY (kg) & 7290 & 160 & 6906 & 140 & 7290 & 412 & 0.781 \\
\hline & FY (kg) & 306 & 76 & 289 & 86 & 317 & 110 & 0.867 \\
\hline & FP $(\%)$ & 4.21 & 0.04 & 4.18 & 0.04 & 4.22 & 0.10 & 0.918 \\
\hline & PY (kg) & 246 & 6 & 230 & 5 & 250 & 15 & 0.989 \\
\hline & PP (\%) & 3.38 & 0.02 & 3.32 & 0.02 & 3.34 & 0.05 & 0.186 \\
\hline & $\mathrm{DM}(\mathrm{kg})$ & 960 & 21 & 904 & 19 & 982 & 57 & 0.910 \\
\hline & DMP (\%) & 13.18 & 0.06 & 13.08 & 0.05 & 13.12 & 0.13 & 0.496 \\
\hline & SCC $(\log 10)$ & $2.17 \mathrm{a}$ & 0.03 & 2.27 & 0.03 & $2.40 \mathrm{a}$ & 0.08 & 0.005 \\
\hline \multirow{8}{*}{ 1-2 together } & MY (kg) & 8392 & 176 & 8286 & 137 & 8511 & 350 & 0.174 \\
\hline & FY (kg) & 365 & 9 & 353 & 7 & 354 & 20 & 0.080 \\
\hline & FP (\%) & 4.36 & 0.06 & 4.27 & 0.05 & 4.13 & 0.13 & 0.292 \\
\hline & PY (kg) & 290 & 6 & 280 & 4 & 288 & 12 & 0.084 \\
\hline & $\mathrm{PP}(\%)$ & 3.53 & 0.03 & 3.47 & 0.02 & 3.49 & 0.06 & 0.405 \\
\hline & $\mathrm{DM}(\mathrm{kg})$ & 1118 & 23 & 1090 & 18 & 1109 & 49 & 0.091 \\
\hline & DMP (\%) & 13.55 & 0.09 & 13.46 & 0.08 & 13.40 & 0.21 & 0.640 \\
\hline & SCC $(\log 10)$ & $2.25 \mathrm{a}$ & 0.03 & $2.35 \mathrm{a}$ & 0.02 & 2.43 & 0.07 & 0.007 \\
\hline \multirow{8}{*}{$1-2-3$ together } & MY (kg) & 8894 & 184 & 8864 & 165 & 9106 & 424 & 0.920 \\
\hline & FY (kg) & 392 & 9 & 383 & 8 & 392 & 22 & 0.832 \\
\hline & FP (\%) & 4.42 & 0.06 & 4.32 & 0.04 & 4.30 & 0.11 & 0.583 \\
\hline & PY (kg) & 301 & 6 & 296 & 5 & 307 & 15 & 0.737 \\
\hline & $\mathrm{PP}(\%)$ & 3.59 & 0.11 & 3.51 & 0.10 & 3.44 & 0.04 & 0.488 \\
\hline & $\mathrm{DM}(\mathrm{kg})$ & 1181 & 24 & 1165 & 22 & 1200 & 59 & 0.875 \\
\hline & DMP (\%) & 14.35 & 0.75 & 13.76 & 0.38 & 13.42 & 0.19 & 0.441 \\
\hline & $\mathrm{SCC}(\log 10)$ & $2.36 \mathrm{~A}$ & 0.03 & $2.48 \mathrm{~A}$ & 0.02 & 2.47 & 0.06 & 0.004 \\
\hline
\end{tabular}

Significant associations are marked in bold. Means marked by the same small letter differ at the significance threshold of $\mathrm{P}<0.05$ and means marked by the same capital letter differ at $\mathrm{P}<0.01$.

Table 2 presents the distribution of genotypes and allele frequency in the analyzed population of Holstein cows. The $\mathrm{C}$ allele was rarer $(0.37)$ than the $\mathrm{T}$ allele $(0.63)$. Heterozygotes were found the most frequently (55\%) in comparison to homozygotes CC and TT $(10.0 \%$ and $35.0 \%$, respectively).

The chi-square test showed that the frequencies of genotypes within the cattle population under study were in agreement with the Hardy-Weinberg equilibrium.
An association study (Table 3 ) revealed that cows with the TT genotype showed significantly lower somatic cell counts than those with the $\mathrm{CC}$ genotype during the first lactation $(\mathrm{P}=0.023)$. During $1-2$ lactations, cows with genotype TT consistently had significantly lower SCC than heterozygotes CT $(\mathrm{P}=0.025)$. The mean value of SCC during 1-3 lactations for cows with the TT genotype was significantly lower than those with genotype CT $(\mathrm{P}=0.006)$ and was also lower than op- 
posite homozygotes $\mathrm{CC}$, but the differences were not significant.

No significant associations between PGLRP1 genotypes and milk production traits were found.

\section{In silico analysis of missense mutation effects}

Bioinformatic analysis of the effects of single amino acid substitution (Y76H) using HOPE software revealed that the substitution of a Tyrosine into a Histidine at position 76 is located within a protein domain, annotated in UniProt as: N-acetylmuramoyl-L-alanine amidase (Wang et al., 2003). The wild-type residue is larger and more hydrophobic than the mutant residue. The mutant residue (His) occurs among the observed residue types at this position in other homologous sequences. This suggests that this variant is not damaging to the protein's structure, but it may modify its function because the mutated residue is located in a domain that is important for the binding of other molecules.

\section{Linkage disequilibrium}

Values of $r^{2}$ and $D^{\prime}$ in the population of 264 Holstein cows and bulls were estimated for six SNPs flanking the PGLYRP1 gene (Figure 3).

No other genes located in the analyzed region were involved in immune system functions.

\section{Discussion}

Therapeutic approaches with antimicrobial drugs have very little effect, especially against chronic sub- clinical mastitis (Guterbock et al., 1993; Gao et al., 2012; Ruegg, 2017). Moreover, the use of antibiotics is increasingly hard to justify considering bacterial resistance and consumer health (Trevisi et al., 2014). Therefore, looking for candidate genes involved in the immunological processes of the mammary gland seems to be a reasonable approach to select cows resistant to mastitis. The telomere proximal region of BTA18 is rich in QTL markers for milk production traits (Cole et al., 2011; Meredith et al., 2012; Clancey et al., 2019), milking speed (Marete et al., 2018), fertility traits (Moore et al., 2016; Puckowska et al., 2019) mastitis resistance (Kurz et al., 2019), SCS (Bennewitz et al., 2003; Cole et al., 2011; Meredith et al., 2012) and SCC (Ibeagha-Awemu et al., 2016).

Peptidoglycan recognition proteins (PGRPs) are involved in the recognition of pathogen-associated molecular patterns. Well-known pathogen-associated molecular patterns include lipopolysaccharides (LPS) from Gram-negative bacteria and lipoteichoic acid (LTA) from Gram-positive bacteria (Tydell et al., 2006). PGLYRP1 is a basic element of innate immune responses which directly recognize components of potential pathogens. The protein encoded by this gene has been reported to interact with microbes to maintain intestinal homeostasis (Seabury et al., 2010) and has been associated with resistance to Mycobacterium avium ssp. paratuberculosis (Pant et al., 2011) in cattle.

There are many polymorphisms within the PGLYRP1 gene. In the current study, missense SNP rs68268284 was identified, which seems to be important for the binding of other molecules, as was shown in an in silico analysis. Moreover, the SNP is located in close vicinity to a promoter of the gene. Mutations in this region can modulate

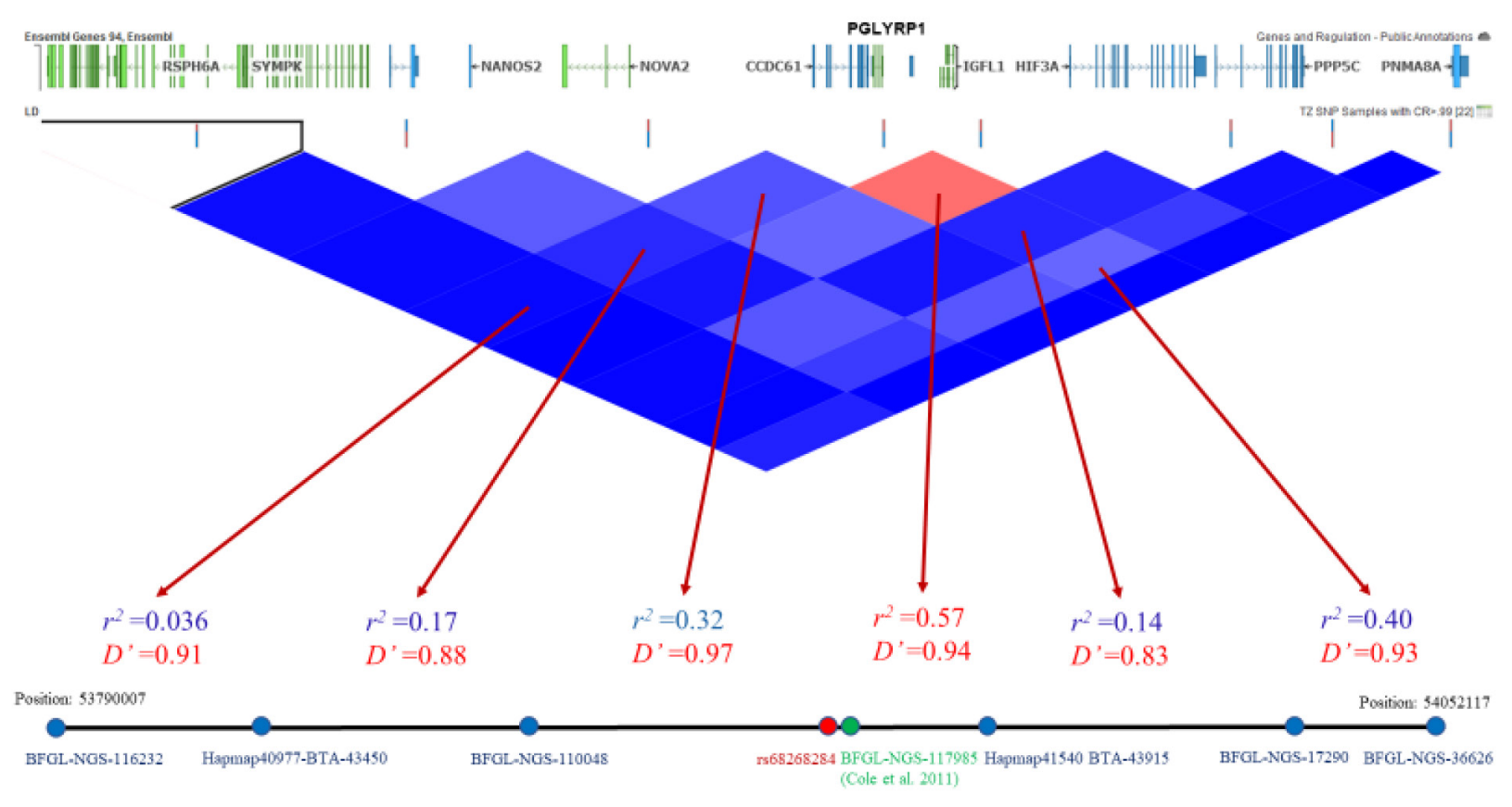

Figure 3. Linkage disequilibrium among SNP rs 108993234 (ARS-BFGL-NGS-117985 Cole et al., 2011) and six nearby SNPs in the population of 264 Holstein cattle. Screenshots originate from the GenomeBrowse ${ }^{\circ}$ visualization tool v. 8.8.3 (Golden Helix, Inc., Bozeman, MT) 
the level of mRNA and protein synthesis (Martin et al., 2002; Zabolewicz et al., 2014). This critical region for PGLYRP1 gene expression has been explored by Wang et al. (2013), who found 10 SNPs within the bovine $P G$ LYRP1 gene. They found associations of SNPs at positions $-35 \mathrm{~T}>\mathrm{A},-12 \mathrm{~T}>\mathrm{G}$ and one synonymous SNP at $+102 \mathrm{G}>\mathrm{C}$ with $\mathrm{SCS}$ in Chinese Holstein cows. Genotype $-35 \mathrm{AA},-12 \mathrm{TT}$ and $+102 \mathrm{CC}$ individually were associated with lower SCS but SNP $+226 \mathrm{~T}>\mathrm{C}$ did not affect this trait. The functional importance of the SNP at position +102 was not confirmed by Pant et al. (2011), who found no association between that SNP and susceptibility to MAP (Mycobacterium avium ssp. paratuberculosis) infection. Pant et al. (2011) did not analyze the associations between T allele at the +226 position and SCC (the same SNP is a subject of the current study), whereas Wang et al. (2013) did it but found no associations with SCS. In the same report, the associations between haplotypes of five subsequent SNPs (located at positions: $-28,+102$, $+226,+312,+1658)$ and SCS were analyzed. The haplotypes which contain the $\mathrm{T}$ allele at position +226 have higher SCS compared to haplotypes with the $\mathrm{C}$ allele. This outcome is contradictory to the current results, in which cows with the TT genotype showed significantly lower somatic SCC than those with the CC genotype (for first lactation) and CT genotype (for 1-2 and 1-3 lactations). The opposite effect of a single SNP to a haplotype of many SNPs, including the SNP of interest, was also shown in Wang et al. (2013) for the SNP at position +102 . This kind of inconsistency can occur when the number of animals in the studies differ significantly. In the work of Wang et al. (2013), a haplotype with the CC genotype at position +226 is represented by ten animals, but in the current study the same genotype was identified in 30 cows. The current results seem to be more reliable because an in silico analysis of the analyzed polymorphism supports the hypothesis that the $\mathrm{C}$ allele (mutant) can modify the binding domain of the protein and therefore can weaken its immunological function, causing a higher number of bacteria in the milk, which can be observed by a higher SCC. Regardless of the differences between the current study and the report of Wang et al. (2013), it can be confirmed that mutations in the PGLYRP1 gene are involved in the response of the cow's mammary gland, as observed by the different somatic cell counts.

In conclusion, it is postulated that missense mutation rs68268284 at position +226 in exon 1 of the bovine PGLYRP1 gene is significantly associated with the somatic cell count in Holstein cows because the mutation may change the functional domain of the PGLYRP1 protein responsible for the ability to bind to other molecules (e.g. pathogens). However, further research is necessary to determine which polymorphisms in the promoter region of PGLYRP1 gene differentiate the quantity of mRNA and also whether a polymorphism at position +226 changes the properties of the PGLYRP1 protein itself.

\section{Acknowledgements}

The authors are very thankful to breeders who provided access to tissue samples and data on the cows.

\section{References}

Baes C., Brand B., Mayer M., Kühn Ch., Liu Z., Reinhardt F., Reinsch N. (2009). Refined positioning of a quantitative trait locus affecting somatic cell score on chromosome 18 in the German Holstein using linkage disequilibrium. J. Dairy Sci., 92: 4046-4054.

Bennewitz J., Reinsch N., Grohs C., Leveziel H., Malafosse A., Thomsen H., Xu N., Looft C. (2003). Combined analysis of data from two granddaughter designs: A simple strategy for QTL confirmation and increasing experimental power in dairy cattle. Genet. Sel. Evol., 35: 319-338.

Brand B., Baes C., Mayer M., Reinsch N., Kühn C. (2009). Identification of a two-marker-haplotype on Bos taurus autosome 18 associated with somatic cell score in German Holstein cattle. BMC Genet., 10: 1-13.

Clancey E., Kiser J.N., Moraes J.G.N., Dalton J., Spencer T.E., Neibergs H.L. (2019) Genome-wide association analysis and gene set enrichment analysis-SNP identify genes associated with 305-day milk yield in Holstein dairy cows. Anim. Genet., 50: 254-258.

Cole J.B., Wiggans G.R., Ma L., Sonstegard T.S., Lawlor T.J. Jr., Crooker B.A., Van Tassell C.P., Yang J., Wang S., Matukumalli L.K., Da Y. (2011). Genome-wide association analysis of thirty one production, health, reproduction and body conformation traits in contemporary U.S. Holstein cows. BMC Genomics, 12: 408.

Detilleux J., Kastelic J.P., Barkema H.W. (2015). Mediation analysis to estimate direct and indirect milk losses due to clinical mastitis in dairy cattle. Prev. Vet. Med., 118: 449-456.

Dziarski R. (2004). Peptidoglycan recognition proteins (PGRPs). Mol. Immunol., 40: 877-886.

Dziarski R., Gupta D. (2006). The peptidoglycan recognition proteins (PGRPs). Genome Biol., 7: 232.

Gao J., Yu F.Q,. Luo L.P., He J.Z., Hou R.G., Zhang H.Q., Li S.M., Su J.L., Han B. (2012). Antibiotic resistance of Streptococcus agalactiae from cows with mastitis. Vet. J., 194: 423-424.

Guterbock W.M., Van Eenennaam A.L., Anderson R.J., Gardner I.A., Cullor J.S., Holmberg C.A. (1993). Efficacy of intramammary antibiotic therapy for treatment of clinical mastitis caused by environmental pathogens. J. Dairy Sci., 76: 3437-3444.

Ibeagha-Awemu E.M., Peters S.O., Akwanji K.A., Imumorin I.G., Zhao X. (2016). High density genome wide genotyping-by-sequencing and association identifies common and low frequency SNPs, and novel candidate genes influencing cow milk traits. Sci. Rep., 6: 31109.

Kang D., Liu G., Lundstrom A., Gelius E., Steiner H. (1998). Isolation, characterization, and antimicrobial properties of bovine oligosaccharide-binding. P. Natl. Acad. Sci. USA, 95: 10078-10082.

Kossaibati M.A., Esslemont R.J. (1997). The costs of production diseases in dairy herds in England. Vet. J., 154: 41-51.

Koressaar T., Lepamets M., Kaplinski L., Raime K., Andreson R., Remm M. (2018). Primer3_masker: integrating masking of template sequence with primer design software. Bioinformatics, 34: 1937-1938.

Kühn C., Bennewitz J., Reinsch N., Xu N., Thomsen H., Looft C., Brockmann G.A., Schwerin M., Weimann C., Hiendleder S., Erhardt G., Medjugorac I., Förster M., Brenig B., Reinhardt F., Reents R., Russ I., Averdunk G., Blümel J., Kalm E. (2003). Quantitative trait loci mapping of functional traits in the German Holstein cattle population. J. Dairy Sci., 86: 360-368.

Kurz J.P., Yang Z., Weiss R.B., Wilson D.J., Rood K.A., Liu G.E., Wang Z. (2019). A genome-wide association study for mastitis resistance in phenotypically well-characterized Holstein dairy cattle using a selective genotyping approach. Immunogenetics, 71: $35-47$. 
Litwińczuk Z., Król J., Brodziak A. (2015). Factors determining the susceptibility of cows to mastitis and losses incurred by producers due to the disease - a review. Ann. Anim. Sci., 15: 819-831.

Liu C., Gelius E., Liu G., Steiner H., Dziarski R. (2000). Mammalian peptidoglycan recognition protein binds peptidoglycan with high affinity, is expressed in neutrophils, and inhibits bacterial growth. J. Biol. Chem., 275: 24490-24499.

Marete A., Sahana G., Fritz S., Lefebvre R., Barbat A., Lund M.S., Guldbrandtsen B., Boichard D. (2018). Genome-wide association study for milking speed in French Holstein cows. J. Dairy Sci., 101: 6205-6219.

Martin P., Szymanowska M., Zwierzchowski L., Leroux C. (2002) The impact of genetic polymorphisms on the protein composition of ruminant milks. Reprod. Nutr. Dev., 425: 433-459.

McConnel C.S., Crisp S.A., Biggs T.D., Ficklin S.P., Parrish L.M., Trombetta S.C., Sischo W.M., Adams-Progar A. (2020). A fixed cohort field study of gene expression in circulating leukocytes from dairy cows with and without mastitis. Front. Vet. Sci., 7: 559279.

Meredith B.K., Kearney F.J., Finlay E.K., Bradley D.G., Fahey A.G., Berry D.P., Lynn D.J. (2012). Genome-wide associations for milk production and somatic cell score in Holstein-Friesian cattle in Ireland. BMC Genet., 13: 21.

Moore S.G., Pryce J.E., Hayes B.J., Chamberlain A.J., Kemper K.E., Berry D.P., McCabe M., Cormican P., Lonergan P., Fair T., Butler S.T. (2016). Differentially expressed genes in endometrium and corpus luteum of Holstein cows selected for high and low fertility are enriched for sequence variants associated with fertility. Biol. Reprod., 94: 1-11.

Pant S.D., Verschoor C.P., Schenkel F.S., You Q., Kelton D.F., Karrow N.A. (2011). Bovine PGLYRP1 polymorphisms and their association with resistance to Mycobacterium avium ssp. paratuberculosis. Anim. Genet., 42: 354-360.

Puckowska P., Borowska A., Szwaczkowski T., Oleński K., Kamiński S. (2019). Effects of a novel missense polymorphism within the SIGLEC5 gene on fertility traits in Holstein-Friesian cattle. Reprod. Domest. Anim., 54: 1163-1168.

Raina V.S., Kour A., Chakravarty A.K., Vohra V. (2020) Marker-assisted selection vis-à-vis bull fertility: coming full circle-a review. Mol. Biol. Rep., 47: 9123-9133.

Ruegg P.L. (2017). A 100-year review: Mastitis detection, management, and prevention. J. Dairy Sci., 100: 10381-10397.

Seabury C.M., Womack J.E. (2008). Analysis of sequence variability and protein domain architectures for bovine peptidoglycan recognition protein 1 and Toll-like receptors 2 and 6. Genomics, 92: $235-245$.
Seabury C.M., Seabury P.M., Decker J.E., Schnabel R.D., Taylor J.F., Womack J.E. (2010). Diversity and evolution of 11 innate immune genes in Bos taurus taurus and Bos taurus indicus cattle. P. Natl. Acad. Sci. USA, 107: 151-156.

Seegers H., Fourichon C., Beaudeau F. (2003). Production effects related to mastitis and mastitis economics in dairy cattle herds. Vet. Res., 34: 475-491.

Sender G., Korwin-Kossakowska A., Pawlik A., Galal Abdel Hameed K., Oprządek J. (2013). Genetic basis of mastitis resistance in dairy cattle - a review. Ann. Anim. Sci., 13: 663-673.

Siatka K., Sawa A., Krężel-Czopek S. (2018). Effect of postpartum endocrine function, metabolism, and mastitis on fertility in highyielding cows - a review. Ann. Anim. Sci., 18: 351-359.

Trevisi E., Zecconi A., Cogrossi S., Razzuoli E., Grossi P., Amadori M. (2014). Strategies for reduced antibiotic usage in dairy cattle farms. Res. Vet. Sci., 96: 229-233.

Tydell C.C., Yount N., Tran D., Yuan J., Selsted M.E. (2002). Isolation, characterization, and antimicrobial properties of bovine oligosaccharide-binding protein. A microbicidal granule protein of eosinophils and neutrophils. J. Biol. Chem., 277: 1965819664.

Tydell C.C., Yuan J., Tran P., Selsted M.E. (2006). Bovine peptidoglycan recognition protein-S: antimicrobial activity, localization, secretion, and binding properties. J. Immunol., 176: 1154-1162.

Venselaar H., Te Beek T.A., Kuipers R.K., Hekkelman M.L., Vriend G. (2010). Protein structure analysis of mutations causing inheritable diseases. An e-Science approach with life scientist friendly interfaces. BMC Bioinf., 11: 548.

Walawski K. (1999). Genetic aspects of mastitis resistance in cattle. J. Appl. Genet., 40: 117-128.

Wang H.L., Li Z.X., Wang L.J., He H., Yang J., Chen L., Niu F.B., Liu Y., Guo J.Z., Liu X.L. (2013). Polymorphism in PGLYRP-1 gene by PCR-RFLP and its association with somatic cell score in Chinese Holstein. Res. Vet. Sci., 95: 508-514.

Wellnitz O., Bruckmaier R.M. (2012). The innate immune response of the bovine mammary gland to bacterial infection. Vet. J., 192: $148-152$.

Zabolewicz T., Barcewicz M., Brym P., Puckowska P., Kamiński S. (2014). Association of polymorphism within LTF gene promoter with lactoferrin concentration in milk of Holstein cows. Pol. J. Vet. Sci., 17: 633-641.

Received: 9 II 2021

Accepted: 9 VIII 2021 